\title{
Y CHROMOSOMAL STR LOCUS DYS385 IN AZOOSPERMIC AND FERTILE MEN FROM THE AEGEAN REGION OF TURKEY: IS THERE ANY FORENSIC RELEVANCE?
}

\author{
Unuvar $\mathrm{D}^{1}$, Baransel Isir $\mathrm{A}^{2}$, Cankus $\mathrm{G}^{3}$, Pehlivan $\mathrm{S}^{3, *}$
}

\begin{abstract}
*Corresponding Author: Associate Professor Sacide Pehlivan, Department of Medical Biology and Genetics, Faculty of Medicine, Gaziantep University, Gaziantep, Turkey; Tel./Fax: +90-342360-6028; e-mail: spehlivan@gantep.edu.tr; aybaransel@yahoo.com
\end{abstract}

\section{ABSTRACT}

The DYS385 locus, consisting of two linked short tandem repeat (STR) subloci, is the polymorphic marker on the $\mathrm{Y}$ chromosome. The distribution of DYS385 genotypes was studied in 51 fertile and 49 azoospermic male individuals from the Aegean Region of Turkey. Genotype 14-17 was the most frequently observed genotype, and the gene diversity value of the Aegean population $(n=100)$ was 0.946 in this study. Results of the analyses show that there is a statistically significant difference between azoospermic and fertile males in terms of the DYS385 polymorphism. In addition, the results demonstrate that the DYS385 locus is very useful for human identification in forensic cases and paternity tests in the Aegean Region of Turkey.

Key words: Aegean Region; DYS385 polymorphism; Forensic genetics; Genotypes; Short tandem repeat (STR); Turkey

1 Ege University, Faculty of Science, Department of Biology, Bornova-Izmir-Turkey

2 Gaziantep University, Faculty of Medicine, Department of Forensic Medicine, Sahinbey-GaziantepTurkey

3 Gaziantep University, Faculty of Medicine, Department of Medical Biology and Genetics, SahinbeyGaziantep-Turkey

\section{INTRODUCTION}

The $\mathrm{Y}$ chromosome DNA polymorphism is a male-specific genetic marker. The $\mathrm{Y}$ chromosome contains a record of all the mutational events that occurred in a man's ancestors, reflecting the history of this paternal lineage. Thus, this makes $\mathrm{Y}$ chromosome polymorphisms very useful at different levels, including the study of population history and forensic analysis [1-3]. These polymorphisms include small and large scale rearrangements, such as insertions, deletions, duplications and inversions; and those associated with tandemly repeated DNA sequences ranging from large satellite loci to miniand microsatellites [4].

Studies of Y chromosome short tandem repeats (STRs) have become increasingly important because of their usefulness in forensic and population genetics [4-6]. In forensic cases, Y-linked STRs are particularly useful for the identification of human remains as well as in rape cases with mixed malefemale stain samples [7]. One of the evident applications of the $\mathrm{Y}$ chromosome STR analysis is in rapes committed by azoospermic individuals $[6,8]$.

Recently, a large number of Y-linked STR loci have been characterized as two fragments of variable sizes obtained using a single primer pair. One of these loci, DYS385, which is a highly polymorphic system, has recently been characterized in more de- 
tail regarding repeat structure as well as variability in different populations [8,9]. The DYS385 locus consists of two linked STR subloci that includes a uniform 4 bp repeat structure, GAAA (10). These two alleles of variable sizes are obtained when this locus is amplified through polymerase chain reaction (PCR) by using one primer pair, and it is regarded as a single haplotype. Therefore, haplotype analysis of the DYS385 locus is expected to provide powerful information for forensic casework $[9,11,12]$. In this study, we aim to report the distribution of DYS385 genotypes of 49 unrelated azoospermic and 51 fertile males from the Aegean Region of Turkey, and to arrive at a conclusion as to whether or not the DYS385 is a highly polymorphic STR system for population of the Aegean Region of Turkey.

\section{MATERIALS AND METHODS}

Forty-nine azoospermic males referred to the Family Planning and Infertility Research Treatment Center in the Aegean Region of Turkey and 51 males with proven fertility, were analyzed. Fortynine azoospermic males, who had non obstructive azoospermia and normal endocrine or hereditary findings, were obtained for the present study [13], together with 51 males with proven fertility, who had had a child in the last 5 years. The study was designed in accordance with the Helsinki Declaration of 1975 on human experimentation and signed informed consent was obtained from all enrollees.

Blood samples were taken from all cases. Genomic DNA was extracted from $2 \mathrm{~mL}$ of peripheral blood samples which were collected in tubes containing EDTA as anticoagulant by using a NucleoSpin (Macherey-Nagel GmbH \& Co. KG, Düren, Germany) isolation kit. The primer sequences, as originally described by Gerken et al. (GDB accession nos. L36701 and L36702, unpublished), were used in the PCR. DYS385-1 and DYS385-2B primers were used. These primer sequences are as follows: (DYS385-1) 5'-AGC ATG GGT GAC AGA GCT A-3'; (DYS385-2B) 5'- CCA ATT ACA TAG TCC TCC TTT C-3'.

The PCR was performed according to the method described by Schneider et al. [9]. The PCR amplification protocol was carried out as follows (using a TC-1 thermocycler; Perkin Elmer, Langen, Germany): initial denaturation for 2 minutes at $94^{\circ} \mathrm{C}$ then a touchdown PCR [14] with denaturation for 30 seconds at $94^{\circ} \mathrm{C}$, annealing for 30 seconds at decreasing temperatures of $59-57^{\circ} \mathrm{C}(3 \mathrm{X}$ two cycles at each temperature), extension for 1 minute at $72^{\circ} \mathrm{C}$, followed by 29 cycles as above with at a $56^{\circ} \mathrm{C}$ annealing temperature, and a final extension for 7 minutes at $72^{\circ} \mathrm{C}$. Electrophoretic separation of amplified PCR products was performed using a non denaturing $7 \%$ polyacrylamide gel followed by silver staining. Genotype frequencies and gene diversity value were calculated according to Nei [15].

\section{RESULTS AND DISCUSSION}

The DYS385 genotype frequencies and gene diversity in azoospermic and fertile individuals in the Aegean Region of Turkey are shown in Table 1. A total of nine different alleles $(9,10,11,12,14,16,17$, $19,24)$ were observed and allele 24 was seen only in fertile males. In azoospermic males, genotypes carrying allele 14 were the most frequent with $50.8 \%$ and allele 12 was present in $31 \%$ of fertile males. Overall, 31 different genotypes were found and 22 of these were observed in azoospermic males, while 26 were found in the fertile males. In this study, genotype 14-17 (12\%) was the most common in the Aegean Region of Turkey. In azoospermic males, the frequencies were more evenly distributed with genotype 14-17 (18.3\%), genotype 14-16 (12.2\%) and genotype 11-14 (10.2\%). Frequently seen genotypes in fertile males were 10-16, 11-12, 12-19, 1416 and 17-19, respectively. Genotype 14-17 showed the biggest difference, with a frequency of 0.183 in azoospermic males and a frequency of 0.058 in fertile males. The genotype frequencies differed significantly $(\chi 2: 47.75, p<0.05)$ (Table 1$)$. We can thus say that the polymorphism of DYS385 differs from azoospermic to fertile individuals in the Aegean Region of Turkey.

In previously published studies from other regions of Turkey, a number of different genotypes were described [16-18]. Overall, the alleles 8 to 20 and 24 were present in 64 different genotypes, 33 of which were not observed in the present study, and 10 of which were seen only in this study, but not observed in the other studies. In these previous Turkish studies, genotype 11-14 at the locus DYS385 had been the most frequent allele combination with ratios of $0.0952,0.1416$ and 0.1250 , respectively. 
Table 1. DYS385 genotype frequencies in azoospermic and fertile males from the Aegean Region of Turkey

\begin{tabular}{|c|c|c|c|c|c|c|}
\hline \multirow{2}{*}{$\begin{array}{c}\text { DYS385 Genotype } \\
\text { Allele }\end{array}$} & \multicolumn{2}{|c|}{ Asoospermic $(n=49)$} & \multicolumn{2}{|c|}{ Fertile $(n=51)$} & \multicolumn{2}{|c|}{ Pooled Results $(n=100)$} \\
\hline & $\mathbf{n}$ & Frequency & $\mathbf{n}$ & Frequency & $\mathbf{n}$ & Frequency \\
\hline $9 / 10$ & - & - & 1 & 0.019 & 1 & 0.01 \\
\hline $9 / 11$ & 1 & 0.020 & 2 & 0.039 & 3 & 0.03 \\
\hline $9 / 12$ & - & - & 1 & 0.019 & 1 & 0.01 \\
\hline $9 / 24$ & - & - & 1 & 0.019 & 1 & 0.01 \\
\hline $10 / 10$ & - & - & 1 & 0.019 & 1 & 0.01 \\
\hline $10 / 11$ & 3 & 0.061 & - & - & 3 & 0.03 \\
\hline $10 / 12$ & 1 & 0.020 & 2 & 0.039 & 3 & 0.03 \\
\hline $10 / 16$ & - & - & 4 & 0.078 & 3 & 0.03 \\
\hline $10 / 17$ & 1 & 0.020 & 2 & 0.039 & 3 & 0.03 \\
\hline $10 / 19$ & - & - & 1 & 0.019 & 1 & 0.01 \\
\hline $10 / 24$ & - & - & 1 & 0.019 & 1 & 0.01 \\
\hline $11 / 11$ & 1 & 0.020 & 1 & 0.019 & 2 & 0.02 \\
\hline $11 / 12$ & 1 & 0.020 & 4 & 0.078 & 5 & 0.05 \\
\hline $11 / 14$ & 5 & 0.102 & 2 & 0.039 & 7 & 0.07 \\
\hline $11 / 16$ & 1 & 0.020 & 2 & 0.039 & 3 & 0.03 \\
\hline $11 / 17$ & 1 & 0.020 & - & - & 1 & 0.01 \\
\hline $11 / 19$ & 1 & 0.020 & - & - & 1 & 0.01 \\
\hline $11 / 24$ & - & - & 1 & 0.019 & 1 & 0.01 \\
\hline $12 / 12$ & 1 & 0.020 & 1 & 0.019 & 2 & 0.02 \\
\hline $12 / 14$ & 1 & 0.020 & 1 & 0.019 & 2 & 0.02 \\
\hline $12 / 16$ & 4 & 0.081 & 1 & 0.019 & 5 & 0.05 \\
\hline $12 / 17$ & 2 & 0.040 & 2 & 0.039 & 4 & 0.04 \\
\hline $12 / 19$ & 1 & 0.020 & 4 & 0.078 & 5 & 0.05 \\
\hline $14 / 14$ & 1 & 0.020 & - & - & 1 & 0.01 \\
\hline $14 / 16$ & 6 & 0.122 & 4 & 0.078 & 10 & 0.10 \\
\hline $14 / 17$ & 9 & 0.183 & 3 & 0.058 & 12 & 0.12 \\
\hline $14 / 19$ & 3 & 0.061 & 2 & 0.039 & 5 & 0.05 \\
\hline $16 / 16$ & 2 & 0.040 & - & - & 2 & 0.02 \\
\hline $16 / 17$ & 2 & 0.040 & 2 & 0.039 & 4 & 0.04 \\
\hline $16 / 19$ & - & - & 1 & 0.019 & 1 & 0.01 \\
\hline $17 / 19$ & 1 & 0.020 & 4 & 0.078 & 5 & 0.05 \\
\hline Total & 49 & 1.000 & 51 & 1.000 & 100 & 1.000 \\
\hline
\end{tabular}

$\chi 2: 47.75, p<0.05$. 
Table 2. Gene diversity of the DYS385 locus in some populations

\begin{tabular}{|c|c|c|c|}
\hline $\mathbf{n}$ & Gene Diversity & Population & References \\
\hline 146 & $0.870(87 \%)$ & Germany & 9 \\
\hline 100 & $0.950(95 \%)$ & China & 9 \\
\hline 100 & $0.930(93 \%)$ & Japan & 9 \\
\hline 95 & $0.960(96 \%)$ & Thailand & 9 \\
\hline 125 & $0.945(95 \%)$ & Italy & 11 \\
\hline 270 & $0.960(96 \%)$ & Japan (Miyazaki) & 31 \\
\hline 117 & $0.984(98 \%)$ & Japan & 19 \\
\hline 316 & $0960(96 \%)$ & Korea & 20 \\
\hline 140 & $0.825(83 \%)$ & Portugal & 21 \\
\hline 120 & $0.925(93 \%)$ & Mexico & 22 \\
\hline 152 & $0.710(71 \%)$ & Lithuania & 23 \\
\hline 145 & $0.703(70 \%)$ & Latvia & 23 \\
\hline 133 & $0.780(78 \%)$ & Estonia & 23 \\
\hline 84 & $0.952(95 \%)$ & Turkey (Marmara) & 16 \\
\hline 111 & $0.825(83 \%)$ & Spain (Southwest) & 24 \\
\hline 200 & $0.960(96 \%)$ & Turkey & 18 \\
\hline 51 & $0.615(62 \%)$ & Spain (Majorca) & 25 \\
\hline 38 & $0.725(73 \%)$ & Spain (Minorca) & 25 \\
\hline 20 & $0.755(76 \%)$ & Spain (Valencia) & 25 \\
\hline 149 & $0.943(94 \%)$ & Thailand (North) & 26 \\
\hline 116 & $0.950(95 \%)$ & Japan (Tottori) & 12 \\
\hline 158 & $0.930(93 \%)$ & Japan (Thane) & 12 \\
\hline 131 & $0.950(95 \%)$ & Japan (Amami) & 12 \\
\hline 94 & $0.950(95 \%)$ & Korea (Soeul) & 12 \\
\hline 113 & $0.953(95 \%)$ & Turkey (Central Anatolia) & 17 \\
\hline 112 & $0.890(89 \%)$ & China & 27 \\
\hline 260 & $0.942(94 \%)$ & USA (African American) & 28 \\
\hline 244 & $0.838(84 \%)$ & USA (Caucasian) & 28 \\
\hline 143 & $0.901(90 \%)$ & USA (Hispanic) & 28 \\
\hline 133 & $0.861(86 \%)$ & Austria & 29 \\
\hline 357 & $0.925(93 \%)$ & Mexico (Chihuahua-Jalisco) & 30 \\
\hline 100 & $0.946(94 \%)$ & Turkey (Aegean) & This study \\
\hline
\end{tabular}


While DYS385 had an exclusion chance of 0.917 in azoospermic males, this value was 0.949 in fertile males. For the combined subjects, this value was 0.946 . This confirmed the results of the previous Turkish studies [16-18]. These results demonstrate that the DYS385 locus is very useful for human identification in forensic cases and paternity tests in the Aegean Region of Turkey.

When our results were compared with other previously published studies [9,11,12,19-30] from Asia, Europe and the USA, different results for the DYS385 locus were obtained in a population from Spain, Portugal, USA, Latvia, etc., and similar results in a population from China, Japan, USA, Italy, etc. (Table 2). From the results of the table, it can be seen that the gene diversity of the DYS385 locus was very high but varied in the different populations.

In conclusion, this is the first study about the DYS385 gene polymorphism in the Aegean Region of Turkey, and in which azoospermic and fertile males were compared for the first time. Results of the present study reveal quite a high genetic diversity of the DYS385 locus, and different genotype frequencies could be seen in many regions of Turkey. At the same time, the results demonstrate that the DYS385 locus is very useful for human identification in forensic cases and paternity tests.

\section{REFERENCES}

1. Gusmão L, Brion M., González-Neira A, Sánchez-Diz P, Lareu MV, Carracedo A. Y chromosome specific polymorphisms in forensic analysis. Legal Med 1999; 1(2): 55-60.

2. Gusmão L, Alves C, Costa S, Amorim A, Brion M, González-Neira A, Sánchez-Diz P, Carracedo A. Point mutations in the flanking regions of the Y chromosome specific STRs DYS391, DYS437 and DYS438. Int J Legal Med 2002; 116(6): 322-326.

3. Quintana-Murci L, Krausz C, McElreavey $\mathrm{K}$. The human Y chromosome: function, evolution and disease. (Review) Forensic Sci Int 2001; 118(2-3): 169-181.

4. Jobling MA, Tyler-Smith C. Fathers and sons: the $\mathrm{Y}$ chromosome and human evolution. Trends Genet 1995; 11(11): 449-456.

5. Jobling MA, Pandya A, Tyler-Smith C. The
Y chromosome in forensic analysis and paternity testing. Int J Legal Med 1997; 110(3): 118-124.

6. Gusmão L, González-Neira A, Pestoni C, Brión M, Lareu MV, Carracedo A. Robustness of the Y STRs DYS19, DYS389 I and II, DYS390 and DYS393: optimization of a PCR pentaplex. Forensic Sci Int 1999; 106(3): 163-172.

7. Schneider PM, d'Aloja E, Dupuy BM, Eriksen B, Jangblad A, Kloosterman AD, Kratzer A, Lareu MV, Pfitzinger H, Rand S, Scheithauer R, Schmitter H, Skitsa I, Syndercombe-Court D, Vide MC. Results of collaborative study regarding the standardization of the Y-linked STR system DYS385 by the European DNA Profiling (EDNAP) group. Forensic Sci Int 1999; 102(2-3): 159-165.

8. Park MJ, Shin KJ, Kim NY, Yang WI, Cho $\mathrm{SH}$, Lee HY. Characterization of deletions in the DYS385 flanking region and null alleles associated with AZFc microdeletions in Koreans. J Forensic Sci 2008; 53(2): 331-334.

9. Schneider PM, Meuser S, Waiyawuth W, Seo Y, Rittner C. Tandem repeat structure of the duplicated Y-chromosomal STR locus DYS385 and frequency studies in the German and three Asian populations. Forensic Sci Int 1998; 97(1): 61-70.

10. Toscanini U, Gusmão L, Berardi G, Amo$\operatorname{rim}$ A, Carracedo A, Salas A, Raimondi E. Y chromosome microsatellite genetic variation in two Native American populations from Argentina: population stratification and mutation data. Forensic Sci Int Genet 2008; 2(4): 274-280.

11. Caglià A, Dobosz M, Boschi I, d'Aloja E, Pascali VL. Increased forensic efficiency of a STR-based Y-specific haplotype by addition of the highly polymorphic DYS385 locus. Int J Legal Med 1998; 111(3): 142-146.

12. Ago K, Seo Y, Yuasa I, Umetsu K, Park KS, Ago M, Ogata M. Distribution of DYS385 genotypes in several Japanese subpopulations and a Korean population. International Congress Series 2003; 1239: 335-337.

13. Okutman-Emons O, Pehlivan S, Tavmergen E, Tavmergen-Goker EN, Ozkinay F. Screening of $\mathrm{Y}$ chromosome microdeletion which contains AZF regions in 71 Turkish azoospermic men. Genet Couns 2004; 15(2): 199-205.

14. Don RH, Cox PT, Wainwright BJ, Baker 
K, Mattick JS. 'Touchdown' PCR to circumvent spurious priming during gene amplification. $\mathrm{Nu}-$ cleic Acids Res 1991; 19(14):4008.

15. Nei M. Analysis of gene diversity in subdivided populations. Proc Natl Acad Sci USA 1973; 70(12): 3321-3323.

16. Cakir AH, Celebioglu A. Y-chromosomal STR haplotypes at the loci DYS19, DYS385, DYS38911, DYS390, DYS391, and DYS393 in Marmara Region of Turkey. J Forensic Sci 2003; 48(1): 215-217.

17. Cakir AH, Celebioðlu A, Yardimci E. YSTR haplotypes in Central Anatolia Region of Turkey. Forensic Sci Int 2004; 144(1): 59-64.

18. Asicioglu F, Akyuz F, Cetinkaya U, Canli MA. Allele and haplotype frequencies of Y-short tandem repeat loci in Turkey. Croat Med J 2003; 44(3): 310-314.

19. Ago K, Yuasa I, Umetsu K, Ago M, Ogata M. Y-chromosomal STR haplotyping in a Japanese population. Legal Med 2000; 2(3): 163-165.

20. Shin DJ, Jin HJ, Kwak KD, Choi JW, Han MS, Kang PW, Choi SK, Kim W. Y chromosome multiplexes and their potential for the DNA profiling of Koreans. J Legal Med 2001; 115(2):109117.

21. Aler M, Salas A, Sanchez-Diz P, Murcia E, Carracedo A, Gisbert M. Y chromosome haplotypes from a Western Mediterranean population sample. Forensic Sci Int 2001; 119(2):254-257.

22. Rangel-Villabos H, Jaloma-Cruz AR, Sandoval-Ramirez L, Velarde-Felix JS, GallegosArreola MP, Figuera E. Y chromosome haplotypes for six short tandem repeats (STRs) in a Mexican population. Arch Med Res 2001; 32(3): 232-237.

23. Lessig R, Edelmann J, Krawczak M. Population genetics of Y-Chromosomal microsatellites in Baltic males. Forensic Science Int 2001; 118(23): $153-157$.
24. Gamero JJ, Romero JL, Gonzalez JL, Carvalho M, Anjos MJ, Real FC, Vide MC. Y chromosome STR haplotypes in a southwest Spain population sample. Forensic Sci Int 2002; 125(1): 86-89.

25. Jimenez G, Rigo AP, Castro JA, Ramon M. Allele frequencies of Y chromosome STR loci DYS385 and DYS392 in three eastern Spanish populations. J Forensic Sci 2003; 48(4): 898-900.

26. Bhoopat T, Hohoff C, Steger HF. Identification of DYS385 allele variants by using shorter amplicons and northern thai haplotype data. J Forensic Sci 2003; 48(5): 1108-1112.

27. Tie J, Wang X, Suzuki Y, Tsukamoto S, Oshida S. Polymorphism of six Y-chromosome STRs in a Chinese population. Legal Med 2004; 6(1): 41-46.

28. Schoske R, Vallone PM, Kline MC, Redman JW, Butler JM. High-throughput Y-STR typing of U.S. populations with 27 regions of the $Y$ vhromosome using two multiplex PCR assays. Forensic Sci Int 2004; 139(2-3): 107-121.

29. Niederstatter $H$, Berger $B$, Oberacher $H$, Brandstatter A, Huber C, Parson W. Evaluation of the forensic usefulness of the separate analysis of DYS385a and DYS385b in an Austrian population sample. International Congress Series 2004; 1261: 360-362.

30. Luna-Vázquez A, Vilchis-Dorantes G, Aguilar-Ruiz MO, Bautista-Rivas A, Pérez-García A, Orea-Ochoa R, Villanueva-Hernández D, Muñoz-Valle JF, Rangel-Villalobos H. Haplotype frequencies of the PowerPlex Y system in a Mexican-Mestizo population sample from Mexico City. Forensic Sci Int Genet 2008; 2(1): e11-3.

31. Seo Y, Takami Y, Nakayama T, Takahama K. Y Chromosome DNA polymorphisms and their haplotypes in a Japanese population. Legal Med 1999; 1(3): 145-149. 